\title{
Corrigendum
}

\section{Identification of SOX2 as a novel glioma-associated antigen and potential target for $T$ cell-based immunotherapy}

\section{Schmitz, A Temme, V Senner, R Ebner, S Schwind, S Stevanovic, R Wehner, G Schackert, HK Schackert, M Fussel, M Bachmann, EP Rieber and B Weigle}

British Journal of Cancer (2007) 96, 1928. doi:I0.1038/sj.bjc.6603802 www.bjcancer.com

Published online 12 June 2007

(c) 2007 Cancer Research UK

Correction to: British Journal of Cancer (2007) 96, 1293-1301. doi: $10.1038 / 6603696$

In the abstract of the above paper, a peptide with correct sequence (TLMKKDKYTL) is mentioned. This sequence should also appear in Table 1 as the sequence of peptide 60031. Unfortunately, an incorrect sequence (ALSPASSRSV) was included in Table 1 (all other data in the respective line of the table are correct and refer to peptide TLMKKDKYTL).

The corrected Table 1 is shown below.

Table I Prediction of HLA-A*020 I-restricted SOX2-derived peptides and determination of binding affinities by a competition assay

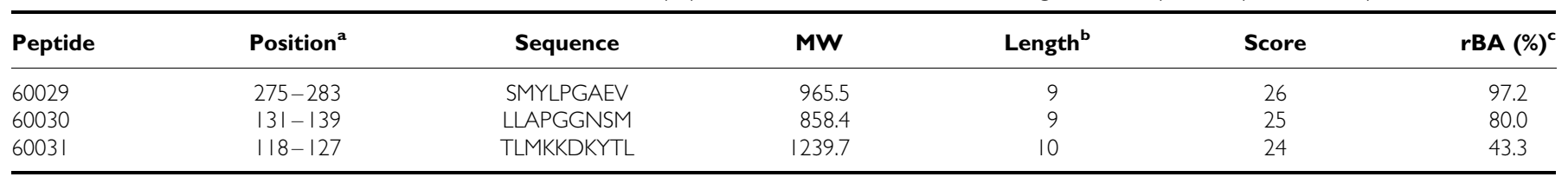

$\mathrm{MW}=$ molecular weight; $\mathrm{r} \mathrm{BA}=$ relative binding affinity. ${ }^{\mathrm{a}}$ The given numbers indicate the position of the peptide in the amino-acid sequence of SOX2. ${ }^{b} \mathrm{Number}$ of amino acids. ${ }^{\top}$ The relative binding affinities were determined by comparing the inhibition of the reporter peptide binding by the analysed peptides in relation to the inhibition obtained with a positive control peptide, which was set as 100\%. The positive control peptide was YLLPAIVHI from RNA helicase p72 and the reporter peptide was ILK(FITC)EPVHGV from $\mathrm{HIV}$-I reverse transcriptase. All peptides were used at a concentration of $10 \mu \mathrm{M}$. 